\title{
Computer Assisted Language Learning
}

\section{Artefact co-construction in virtual exchange: 'Youth Entrepreneurship for Society'}

\section{Ana Sevilla-Pavón \& Anna Nicolaou}

To cite this article: Ana Sevilla-Pavón \& Anna Nicolaou (2020): Artefact co-construction in virtual exchange: 'Youth Entrepreneurship for Society', Computer Assisted Language Learning, DOI: 10.1080/09588221.2020.1825096

To link to this article: https://doi.org/10.1080/09588221.2020.1825096

View supplementary material $[\pi$

曲 Published online: 12 Oct 2020.

Submit your article to this journal $₫$

Q View related articles $₫$

View Crossmark data \lceil 


\title{
Artefact co-construction in virtual exchange: 'Youth Entrepreneurship for Society'
}

\author{
Ana Sevilla-Pavón ${ }^{a}$ (D) and Anna Nicolaou ${ }^{b}$ \\ aIULMA/Universitat de València, València, Spain; 'banguage Centre, Cyprus University of \\ Technology, Limassol, Cyprus
}

\begin{abstract}
The aim of this research study around the co-construction and sharing of authentic and meaningful artefacts within the 'Youth Entrepreneurship for Society' virtual exchange was to find out how the implementation of artefact-based telecollaborative tasks fosters 21 st competences and social entrepreneurship in English for Specific Purposes settings. The project tasks were informed by constructionism and supported virtual collaboration an effort to promote social justice. They revolved around social entrepreneurship in English for Specific Purposes contexts, aiming to connect the classroom with the outside world through the involvement of local organisations, while fostering students' twenty-first century competences: intercultural, linguistic, digital and teamwork as well as social entrepreneurial mindset. The two research questions which guided the study were: (1) How does the implementation of artefactbased tasks in English for Specific Purposes contexts contribute to students' perceived development of twenty-first century competences? (2) In what ways can the implementation of artefact-based telecollaborative tasks foster social entrepreneurship in English for Specific Purposes contexts? The results of the study conducted with 42 participants indicate that the virtual exchange was perceived as having positively contributed to connecting the classroom with the outside world through the involvement of mentor civil organisations, while fostering students' twenty-first century competences.
\end{abstract}

Abbreviations: CUT: Cyprus University of TechnologyELT English Language Teching ESAP English for Specific Academic Purposes; ESP: English for Specific Purposes; NGOs: non-governmental organisations; RQ1: first research question; RQ2: second research question; SDGs: sustainable development goals; UV: Universitat de València; YES: Youth Entrepreneurship for Society

\section{KEYWORDS}

Artefact construction; constructionism; Critical CALL; English for Specific Purposes; twenty-first century competences; virtual exchange 


\section{Introduction}

Foreign language virtual exchange or telecollaboration refers to virtual intercultural interaction and exchange projects between classes of foreign language learners in geographically distant locations (O'Dowd, 2011). This article deals with the co-construction and sharing of authentic and meaningful artefacts between classes of foreign language learners in Cyprus and Spain within the 'Youth Entrepreneurship for Society' $(\mathrm{YES})^{1}$ virtual exchange project. The project was carried out between the Cyprus University of Technology (CUT, Cyprus) and the Universitat de València (UV, Spain) with students enrolled in Business Communication and Management courses. It aimed to foster Social Entrepreneurship in English for Specific Purposes (ESP) contexts, while promoting the development of twenty-first century competences: linguistic, intercultural, digital and teamwork (Partnership for 21st Century Skills, 2009) as well as social entrepreneurial mindset. Thanks to sustained foreign language virtual exchange and the involvement of different local organisations, students could work on making collective and socially engaged artefacts regardless of time-space constraints.

The project's tasks followed O'Dowd and Waire's (2009) typology and thus they comprised Information Exchange, Comparison and Analysis, as well as Collaboration tasks, in the form of interactions on the Google + Community to discuss and complete activities about stereotypes, experiences communicating in the L2, the creation of a digital story and the delivery of an elevator pitch about an innovative product or technology aimed at addressing any of the social challenges currently being faced by the mentor organisations (Sevilla-Pavón, 2019).

Salmon's model for online learning (2013) was employed for the structuring of tasks and activities. Salmon's model is a five-stage model that can be used for designing online activities. The five stages comprising the model are: Access and Motivation, Online Socialisation, Information Exchange, Knowledge Construction and Development. The specific model was used to advise the structuring of the task sequence of the project as it can assist the designer in developing motivating activities while helping participants to socialise and build up knowledge with others in the same online community (Erkmann, Petersen, \& Christensen, 2019). Salmon's model provides a framework whereby students are scaffolded to gradually move through the stages with a 'positive progression in the quality and intensity of interaction between students and between students and their teachers' (Muirhead, 2002, p. 1). Supporting Information Annex 1 presents an overview of the tasks and activities. Samples of these tasks as well as information about suggested assessment criteria, recommended tools, resources and notes for the teacher can be found in 
Sevilla-Pavón and Nicolaou (2019). Furthermore, learning was taken beyond the classroom's four walls by connecting the topics dealt with in class with the outside world. This was done in an effort to raise students' awareness about different societal issues while fostering the development of the aforementioned twenty-first century competences (SevillaPavón, 2019).

In order to achieve the project's main goals, a Critical CALL perspective was adopted, and the project was grounded under the theoretical framework of constructionism. This framework was deemed the most appropriate theory of learning, teaching and design because of its alignment with the demands and expectations of computational culture, as well as its emphasis on building, creating and making shared and meaningful artefacts for knowledge acquisition (Papert, 1980, 1993).

The aspects under investigation were motivation, intercultural competence and awareness, linguistic competence, teamwork, digital competence, social entrepreneurship and level of anxiety. Motivation and anxiety were examined in order to gain insight into the participants' overall feelings about the exchange. Intercultural competence and awareness are at the core of any twenty-first century learning model. In the Partnership for 21st Century Skills (P21) framework which guided this study, global awareness is described as the ability to use, understand and respond to global issues as well as the ability to work and collaborate with individuals hailing from diverse cultural backgrounds with an attitude of respect. As for linguistic competence, the P21 framework emphasises this skill as the ability to communicate effectively in diverse environments and contexts. Teamwork is reflected in P21 as the ability to collaborate with others effectively and respectfully. The framework also highlights collaboration within diverse teams and willingness to value individual contributions. Digital competence is demonstrated in the framework as the ability to access, manage, use and evaluate information critically (Partnership for 21st Century Skills, 2009). Finally, social entrepreneurial mindset was examined in the sense of the ability of individuals and organisations to adopt a humanistic role and embrace social transformation through innovative business solutions. With this in mind, the study was guided by the following research questions:

1. How does the implementation of artefact-based tasks in English for Specific Purposes contexts contribute to students' perceived development of 21st century competences?

2. In what ways can the implementation of artefact-based telecollaborative tasks foster social entrepreneurship in English for Specific Purposes contexts? 
A combination of quantitative and qualitative data was used to answer the research questions. Specifically, the study's quasi-experimental, onegroup Pretest-Posttest design was employed in order to observe the extent to which the implementation of artefact-based tasks in virtual exchange embedded in ESP learning had affected the students' perceptions on the development of twenty-first century skills, such as intercultural, linguistic, digital, teamwork, as well as social entrepreneurial mindset. As this type of experimental design has minimal internal validity and no external validity due to the lack of a control group and the fact that participants were not randomly assigned to different groups, additional data were collected for triangulation purposes. Therefore, the research questions were also answered by analysing qualitative data gathered by means of focus groups with and written reflections from students. In addition, a thematic analysis of the students' digital artefacts was performed in order to explore the ways in which the implementation of artefact-based telecollaborative tasks can foster social entrepreneurship in ESP contexts. To the authors' knowledge, no previous studies have ever attempted to address these questions, and thus, the impact of artefact co-construction in the development of twenty-first century competences within virtual exchange projects revolving around social entrepreneurship remains widely unexplored.

\section{Overview of previous studies}

Content-based virtual exchange projects or discipline-specific telecollaboration projects which are directed towards the production of different genres beyond 'the genre of personal conversation' (O'Dowd, 2016, p. 3) are sporadic in the literature. For the purposes of this study, an overview of other relevant content-based virtual studies was performed. One such study refers to a genre-based telecollaboration for content and language learning (Cunningham, 2019). This project was implemented in a university-level business German course and required students to interact synchronously with entrepreneurs in Berlin in order to develop their knowledge of German business culture. Two more studies that were implemented within an international, business-oriented approach were reported by Lindner (2016) and Taras et al. (2012), respectively. The former reports on an exchange between students at the University of Paderborn in Germany and Masaryk University in Brno in the Czech Republic which was implemented within English for Specific Academic Purposes (ESAP) courses for Business and Economics. This exchange aimed at developing intercultural competence in global virtual teams through virtual exchange while at the same time offering students the opportunity to develop workplace skills (Lindner, 2016). The latter 
reports on the X-Culture Project, which was designed to enhance learning in International Business courses through large-scale international collaboration projects embedded in business courses and corporate training (Taras et al., 2012). While the three aforementioned studies provided valuable examples of enriching the university curricula through transnational, technology-mediated collaborative learning within specific-discipline-based courses, the aspect of 'criticality' in Computer-Assisted Language Learning was explored in different telecollaboration initiatives, such as the Soliya Connect Program (Helm, 2013), which presents a dialogic model of telecollaboration building 'Critical Framing directly into the task design' (Guth \& Helm, 2010, p. 96) by engaging students from Western and Arab countries in facilitated, synchronous conversation over controversial topics, such as war and terrorism (Genet, 2010).

With regard to artefact co-construction and the development of twentyfirst century skills such as intercultural citizenship, two interesting studies have been reviewed. One was an initiative by Porto and Byram (2015) which connected students in Argentina and Britain. The project focused on human rights violations during the football World Cup that took place in Argentina in 1978 and involved discussions using Skype and collaborative work towards the creation of awareness-raising leaflets intended to have an impact in the local communities. The particular project was an attempt to combine foreign language and citizenship education aspiring to help young learners become actively engaged in the community. A similar initiative reported by Porto and Yulita (2016) revolved around the Malvinas war, which was fought between Argentina and Britain over the Malvinas Islands (known by the British as Falkland Islands) in 1982. The project connected foreign language students in Argentina and Britain who were involved in online intercultural dialogue using English and Spanish as foreign languages and English as a lingua franca. In this project, students were engaged in the collaborative creation of bilingual leaflets for peace addressed to their local communities. With these projects in mind, the virtual exchange reported in this study adopted a Critical CALL and constructionist design by including community engagement tasks that required the co-construction of meaningful artefacts in an effort to develop the learners' critical twenty-first century competences, while developing social entrepreneurial mindset within ESP learning.

\section{Theoretical framework: connecting constructionism and Critical Computer-assisted Language Learning in a virtual exchange project}

Constructionism is an epistemology and a theory of design and learning which combines two aspects of the theory of science education: on the 
one hand, learning is viewed as a reconstruction rather than as a transmission of knowledge; on the other hand, learning is considered to be 'most effective when part of an activity the learner experiences as constructing a meaningful product' (Papert, 1986, p. 1). Therefore, central to the constructionist view of learning is the idea that learning is more effective and meaningful when students are involved in actively making tangible objects known as artefacts - in the real world. This in turn highlights the importance of tools, media and context in human development (Ackermann, 2001) in the process of transcending the foreign language classroom so as to achieve the ultimate objective of school education, which is to learn for life rather than for school (Kohn \& Hoffstaedter, 2017).

As a result of this learning-by-doing emphasis, constructionism can be said to address 'constructivist learning in individual and social environments where bricolage with digital expressive media plays an important role' (Kynigos \& Futschek, 2015, p. 281). The constructionist experiential and project-based view of learning derives from Piaget's (Cakir, 2008) and Vygotsky's (1978) epistemological and psychological theories of constructivism and socio-constructivism. However, while constructivist approaches tend to focus on the connection between previous knowledge and newly-acquired knowledge by means of step-by-step guidance as well as the interactions with the outside world for the internalisation of concepts, constructionism emphasises the role of the facilitator or coach in a process of using already-known information to acquire new knowledge (Alessandrini \& Larson, 2002). In both constructivism and constructionism, the interaction with the world and its objects is conducive to learning, but constructivism places more emphasis on the importance of construction rather than simple internalisation.

As for Critical Computer-assisted Language Learning (Critical CALL), its origins can be traced back to the broader field of Critical Applied Linguistics and the work of scholars such as Pennycook (2001), who questions 'the role ELT plays as a form of service industry to globalization' (Pennycook, 2016, p. 27). Furthermore, Helm (2015, p. 4) points out that Critical CALL is concerned with 'the relationship between the macro and the micro, an engagement with issues of power and inequality and an understanding of how our classrooms and conversations are related to broader social, cultural and political relations'.

Critical CALL is also intimately related to the Critical Pedagogy framework, which understands being a critical individual as being empowered to seek justice and emancipation. Burbules and Berk (1999) distinguish between the 'Critical Thinking' tradition and the 'Critical Pedagogy' movement, arguing that practitioners of the latter are not necessarily concerned with finding an objective, dispassionate truth; but rather, they 
take the side of people who are disenfranchised from social, economic and political opportunities. Within the Critical Pedagogy framework, pedagogy is seen as a powerful tool which can foster dialogue and activism (Giroux, 2006), as it 'makes clear that schools and other educational spheres cannot be viewed merely as instructional sites, but must be seen as places where culture, power, and knowledge come together to produce particular identities, narratives, and social practices' (Giroux, 2006, p. 4). In addition, the development of a critical consciousness is an essential tool to achieve freedom, as social critique is the way to achieve social justice (Freire, 1981, 2003). According to Freire $(1973,1987)$, the emancipation process begins by acknowledging that we are immersed in a system of oppressive relations and by becoming aware of our place within that oppressive system. This gaining of consciousness helps us develop a liberating praxis. Therefore, education is a key element in fostering this emancipating practice and thus, a social and educational view of justice and equality should be the basis for any kind of didactic initiative, the ultimate goal being the liberation from oppression and human-caused injustices and suffering.

As Ackermann (2001) pointed out, there are many points in which Piaget's constructivism (Piaget, 1936, 1945, 1957), Papert's constructionism (Papert, 1980, 1986, 1993) and Freire's Critical Pedagogy (Freire, 1973, 1987) converge, namely how education is rethought, new environments imagined, new tools and technologies explored, and how students are encouraged to find their own voices and to exchange their ideas. In line with this view, adopting a Constructionist Critical CALL approach involves encouraging students' critical analysis of reality and the current challenges society faces with a view to achieving equality, social justice and awareness about the different issues dealt with. In the YES project, this was done through the completion of different iterative cycles which comprised theory, practice, evaluation and reflection (Freire, 2003) and by bringing in different social organisations and non-governmental organisations (NGOs) from the civil society which provided students with information about their mission and main activities (Sevilla-Pavón, 2019). These organisations also guided students when finding and developing their ideas for the main artefacts they co-constructed: digital stories and elevator pitches (Sevilla-Pavón \& Nicolaou, 2017, 2020). Supporting Information Annexes 2 and 3 identify those organisations from Spain and Cyprus and their respective missions (Nicolaou, 2020; Sevilla-Pavón, 2019).

\section{Methodology}

A mixed-methods approach was adopted, involving data collection from various sources in order to answer the research questions: pre- and post- 
intervention questionnaires (see Supporting Information Annex 4), focus group interviews and written reflections with participants, as well as the analysis of the artefacts produced.

The quantitative data obtained by means of the pre- and post-intervention questionnaires constituted the basis for the present study. An independent samples $t$-test was conducted on SPSS in order to measure whether the means of the participants' perceptions had varied upon completion of the project. This quantitative analysis was supported by qualitative data from the participants' comments about their perceptions of different aspects of the exchanges in both the open-ended questions of the post-questionnaire, the focus group interviews and written reflections, as well as through a thematic analysis of the students' digital artefacts.

\subsection{Settings and participants}

Forty-two $(N=42)$ students from CUT and UV took part in the YES project and completed both the pre- and post-questionnaires. In addition, they participated in the focus group interviews. They were aged between 18 and 25 and they were enrolled in Business Management and Communication courses in their respective institutions: 27 from CUT and 15 from UV. Out of the 27 CUT participants, 25 were Cypriot and 2 were Greek. Meanwhile, 11 of the UV participants were Spanish, 2 were German and 2 were Russian and Austrian, respectively. Since this was an L2 virtual exchange, participants interacted in English at a B2 level according to the Common European Framework of Reference for Languages (Council of Europe, 2001). Their interactions took place in a Google + Community named CUT-UV 2017 Telecollaboration while collaborative task completion took place using collaborative tools, such as Google Drive (Google Docs and Google Slides).

Participants worked in international groups of 4 and interacted both synchronously and asynchronously using English as a lingua franca over the course of one semester ( 15 weeks, from September to December). They completed a range of tasks which involved getting in touch with the 22 aforementioned local associations and NGOs from Spain and Cyprus (11 Spanish and 11 Cypriot), identifying the main challenges faced by those organisations, discussing and providing solutions linked to their local communities' social issues through virtual exchange, and presenting their own initiatives in the form of digital stories and elevator pitches which were delivered at the end of the semester in a fictitious Social Entrepreneurship fair (Sevilla-Pavón, 2019). The YES project was informed by the principles of Education for Sustainable Development (UNICEF, 1993), which has been promoted 
by the United Nations since 1992 as a means to empower individuals to: (a) 'reflect on their own actions, taking into account their current and future social, cultural, economic and environmental impacts, from a local and a global perspective'; and (b) 'act in complex situations in a sustainable manner, which may require them to strike out in new directions; and to participate in socio-political processes, moving their societies towards sustainable development' (UNESCO, 2017). Therefore, critical attitudes and values such as solidarity, equality and respect were fostered, bearing in mind that 'as ELT professionals, we are never just teaching something called English but rather are involved in economic and social change, cultural renewal, people's dreams and desires' (Pennycook, 2016, p. 30).

In line with the view which considers critical learning as 'teaching for social justice, in ways that support the development of active engaged citizens' (Crookes, 2013, p. 9), participants were encouraged to become active 'change champions' and thus they were empowered and made aware of both their capability and responsibility to promote positive change at both the local and institutional levels. In other words, participants became social entrepreneurs, that is, entrepreneurs concerned with developing, funding and implementing solutions to social, cultural or environmental issues (Bornstein, 2007). Therefore, the project supported collaboration and the co-construction of artefacts, within an authentic, meaningful, learner-centred, engaging and challenging knowledge-application and construction process. In this way, the affordances of technology-based initiatives for the promotion of 'social inclusion' (Warschauer, 2003, p. 8) and their usefulness for addressing problems related to discrimination, marginalisation and inequality (Andrejevic, 2007; Menezes de Souza, 2012) were explored.

Throughout the YES project, the topics dealt with and the artefacts to be constructed aimed to promote equality, social justice and 'engaged learning', understood as applying concepts and ideas from the classroom to out-of-class cognition and action. Therefore, they were aligned with the United Nations' Sustainable Development Goals (SDGs; 2015). These belong to the 2030 Agenda for Sustainable Development and comprise a set of 17 'Global Goals' with 169 targets among them (UNESCO, 2005). The 2030 Agenda establishes the targets and steps to be taken so as to stimulate action over the next fifteen years in the following critical areas: People, Planet, Prosperity, Peace, People and Partnership (UNESCO, 2015). As shown in the chart below (Figure 1), the SDGs include a varied range of goals, from poverty reduction to peace and justice and international commitment and cooperation towards achieving these same goals: 


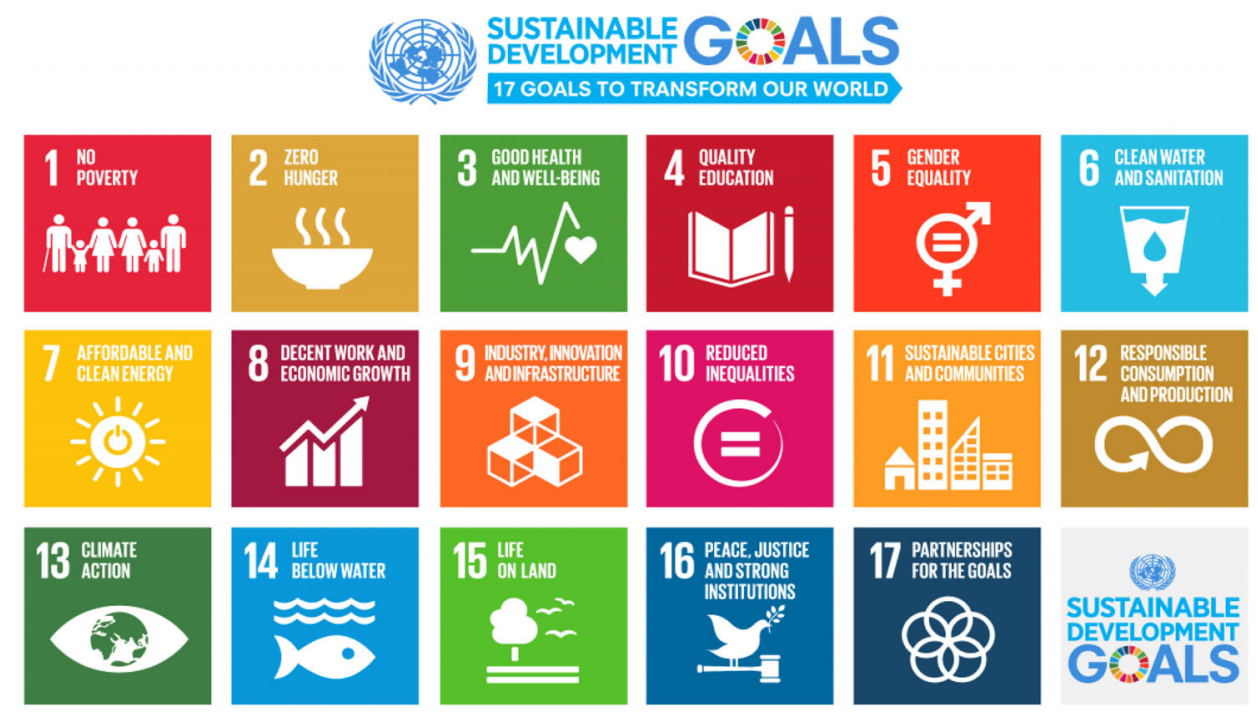

Figure 1. The 17 UNESCO's sustainable development goals. ${ }^{2}$

\subsection{Data gathering}

In order to address (a) the first research question (RQ1), regarding how the implementation of artefact-based tasks in ESP contexts contributed to students' perceived development of twenty-first century competences and (b) the second research question (RQ2), concerning the ways in which the implementation of artefact-based telecollaborative tasks could foster social entrepreneurship in ESP contexts, the target competences were identified and the pre- and post-questionnaire (see Supporting Information Annex 4) were designed accordingly. These pre- and postquestionnaires thus included questions about intercultural, linguistic, digital and interpersonal (teamwork) competences to address RQ1 and social entrepreneurship to address RQ2. The questionnaires (see Supporting Information Annex 4) were completed by participants at the beginning and at the end of the project and included 60 openended and close questions through which both quantitative (in 7-point Likert-scale responses) and qualitative (open responses) were gathered. They comprised six different sections: (A) Demographics and internet and social media use; (B) Motivation and level of anxiety; (C) Language and communication; (D) Teamwork; (E) Intercultural awareness; and (F) Social Entrepreneurship and overall opinion about different aspects of the project.

Section A of the questionnaires included eight closed questions which aimed to gather both demographic data and data about participants' media and Internet usage. As for the questions included in Section B, these were 11 closed questions which revolved around aspects concerning 
the participants' level of motivation before and after co-constructing and sharing their artefacts, as well as how their levels of anxiety were affected by the different tasks they were asked to complete. Regarding Section C, it comprised five closed questions which had to do with their linguistic and communicative competence. In the case of Section $\mathrm{E}$, the questions enquiring about the participants' intercultural awareness were also closed and their total number was 12. Finally, the questions from Section D were open-ended: each of them provided a prompt which respondents had to complete, concerning social entrepreneurship and their opinions about the process of becoming social entrepreneurs responsible for constructing and sharing the different artefacts with their mentor organisations.

In addition, students' feedback was gathered from focus group interviews and written reflections. The questions included a description of the students' experience and the fulfilment of their expectations; an analysis of their learning process and gains, as well as the issues encountered and how they were dealt with; a discussion of the communication strategies used; the project's impact on their view and experience of other cultures or ethnicities; their perceptions regarding the development of different twenty-first century competences (linguistic, teamwork, digital, intercultural and social entrepreneurial); technology affordances; acquisition of specific lexis and knowledge connected to their field of specialisation; and their suggestions for improvement.

\subsection{Data analysis}

The quantitative data gathered by means of pre- and post-questionnaires were analysed with the IBM SPSS Statistics software, version 24. A $t$-test was conducted in order to check the individual differences in pre- and post-intervention responses concerning participants' perceptions of how the implementation of telecollaborative artefact-based tasks in ESP contexts contributes to the development of twenty-first century competences. The variables analysed were coded as: motivation (MOT and MOTP), intercultural competence and awareness (AWA and AWAP), linguistic competence (LING and LINGP), teamwork (TEA and TEAP), digital competence (DIG and DIGP) and level of anxiety (ANX and ANXP).

As for the qualitative data, these were analysed using the NVIVO software, version 11 , to identify specific emerging themes by analysing the content and the sentence structure first and then assigning significance to some themes over others based on how frequently each of them occurred. To ensure inter-coder reliability, checks were conducted on the coding of the emerging themes. Two coders reached an inter-coder agreement of above $80 \%$, and disagreement was resolved through discussion. The 
analysis shed additional light on the participants' perceptions of different aspects of the exchanges thanks to their open-ended questionnaire responses and the focus group interviews in which feedback from students was obtained. Furthermore, the artefacts produced by participants were analysed and categorised according to their content and their alignment with UNESCO's SDGs. In this way, the question of how the implementation of artefact-based telecollaborative tasks fostered social entrepreneurship in ESP contexts was addressed (Tables 1 and 2 below).

Table 1. UV's digital stories' content aligned with the SDGs tackled by each Spanish organisation.

\begin{tabular}{|c|c|c|c|}
\hline $\begin{array}{l}\text { UV digital } \\
\text { artefacts titles }\end{array}$ & $\begin{array}{l}\text { UV digital } \\
\text { artefacts content }\end{array}$ & $\begin{array}{c}\text { Spanish organisations } \\
\text { involved }\end{array}$ & UN SDGs addressed \\
\hline $\begin{array}{l}\text { 'Marmak, the } \\
\text { Water Bubble' }\end{array}$ & $\begin{array}{l}\text { A product to } \\
\text { reduce plastic } \\
\text { pollution }\end{array}$ & DESEEA & $\begin{array}{l}\text { 6: Clean water and sanitation } \\
\text { 14: Life below water (Environment } \\
\text { protection) }\end{array}$ \\
\hline 'SmartArt' & $\begin{array}{l}\text { A product to } \\
\text { reduce energy } \\
\text { consumption }\end{array}$ & $\begin{array}{l}\text { Art and } \\
\text { Environment } \\
\text { Research Centre }\end{array}$ & $\begin{array}{l}\text { 7: Affordable and clean energy } \\
\text { 9: Industry, innovation, infrastructure } \\
\text { 11: Sustainable cities and communities }\end{array}$ \\
\hline $\begin{array}{l}\text { 'Meet your } \\
\text { Foreign Friend' }\end{array}$ & $\begin{array}{l}\text { An app to support } \\
\text { learning in } \\
\text { remote areas }\end{array}$ & CEPAIM & $\begin{array}{l}\text { 4: Quality education } \\
\text { 10: Reduced inequalities } \\
\text { 16: Peace, justice and strong institutions }\end{array}$ \\
\hline 'Charger Bag' & $\begin{array}{l}\text { A product to raise } \\
\text { awareness about } \\
\text { ecology }\end{array}$ & $\begin{array}{l}\text { Malva Community } \\
\text { Radio Station }\end{array}$ & 9: Industry, innovation, infrastructure \\
\hline $\begin{array}{l}\text { 'Umbrella } \\
\text { StanDry' }\end{array}$ & $\begin{array}{l}\text { A product to } \\
\text { support clean } \\
\text { environment }\end{array}$ & AESCO & $\begin{array}{l}\text { 7: Affordable and clean energy } \\
\text { 9: Industry, innovation, infrastructure } \\
\text { 11: Sustainable cities and communities }\end{array}$ \\
\hline 'University Fair' & $\begin{array}{l}\text { A service to } \\
\text { support university } \\
\text { students }\end{array}$ & Jovesolides & $\begin{array}{l}\text { 4: Quality education } \\
\text { 16: Peace, justice and strong institutions }\end{array}$ \\
\hline
\end{tabular}

Table 2. CUT's digital stories content aligned with the SDGs tackled by each Cypriot organization.

\begin{tabular}{|c|c|c|c|}
\hline $\begin{array}{l}\text { CUT digital } \\
\text { artefacts titles }\end{array}$ & $\begin{array}{l}\text { CUT digital } \\
\text { artefacts content }\end{array}$ & $\begin{array}{c}\text { Cypriot organisations } \\
\text { involved }\end{array}$ & SDGs addressed \\
\hline 'Play and help' & $\begin{array}{l}\text { An online game to support } \\
\text { volunteerism and people } \\
\text { in need }\end{array}$ & Funraising & $\begin{array}{l}\text { 1: No poverty } \\
\text { 10: Reduced inequalities } \\
\text { (Children rights) }\end{array}$ \\
\hline ‘Child Dash' & $\begin{array}{l}\text { An app to support children } \\
\text { with mental illnesses }\end{array}$ & $\begin{array}{l}\text { Dancing } \\
\text { Queen Foundation }\end{array}$ & $\begin{array}{l}1 \text { \& 2: No poverty and no } \\
\text { hunger } \\
\text { 4: Quality education, } \\
\text { 10: Reduced inequalities } \\
\text { (Children's rights) }\end{array}$ \\
\hline 'ECO-APP' & $\begin{array}{l}\text { An app to support animal } \\
\text { protection and the } \\
\text { environment }\end{array}$ & $\begin{array}{l}\text { Friends of the } \\
\text { Earth Cyprus }\end{array}$ & $\begin{array}{l}\text { 15: Life on land } \\
\text { (Environment protection) }\end{array}$ \\
\hline 'Cool Car' & $\begin{array}{l}\text { An eco-friendly product to } \\
\text { support young people } \\
\text { with mobility problems }\end{array}$ & $\begin{array}{l}\text { The Centre for the } \\
\text { Provision } \\
\text { of Social Services }\end{array}$ & $\begin{array}{l}\text { 3: Good health and well- } \\
\text { being } \\
\text { 4: Quality education } \\
\text { 10: Reduced inequalities }\end{array}$ \\
\hline 'SpeakUp' & $\begin{array}{l}\text { An app to support } \\
\text { isolated people }\end{array}$ & AEQUITAS & $\begin{array}{l}\text { 3: Good health and } \\
\text { well-being }\end{array}$ \\
\hline 'Dognder' & $\begin{array}{l}\text { An app to support } \\
\text { animal protection }\end{array}$ & Dog Valley Rescue Center & $\begin{array}{l}\text { 15: Life on land } \\
\text { (Animal rights) }\end{array}$ \\
\hline
\end{tabular}


Table 2. Continued.

\begin{tabular}{|c|c|c|c|}
\hline $\begin{array}{l}\text { CUT digital } \\
\text { artefacts titles }\end{array}$ & $\begin{array}{l}\text { CUT digital } \\
\text { artefacts content }\end{array}$ & $\begin{array}{c}\text { Cypriot organisations } \\
\text { involved }\end{array}$ & SDGs addressed \\
\hline 'Visa-Kid' & $\begin{array}{l}\text { A product to support } \\
\text { impoverished children's } \\
\text { needs at schools }\end{array}$ & $\begin{array}{l}\text { Parents Association } \\
\text { Lanitio } \\
\text { Primary School }\end{array}$ & $\begin{array}{l}\text { 1: No poverty } \\
\text { 4: Quality education } \\
\text { 10: Reduced inequalities }\end{array}$ \\
\hline 'EasyPaws' & $\begin{array}{l}\text { A product to support } \\
\text { animals using recycled } \\
\text { materials to make } \\
\text { artificial body parts }\end{array}$ & $\begin{array}{l}\text { Friends of the } \\
\text { Earth Cyprus }\end{array}$ & $\begin{array}{l}\text { 15: Life on land } \\
\text { (Environmental protection } \\
\text { and Animal rights) }\end{array}$ \\
\hline 'Mitro app' & $\begin{array}{l}\text { An app to support charity } \\
\text { organisations and } \\
\text { children in need }\end{array}$ & $\begin{array}{l}\text { Polydynamo Kentro, IERA } \\
\text { MHTROPOLIS LEMESOU }\end{array}$ & $\begin{array}{l}\text { 1: No poverty } \\
\text { 10: Reduced inequalities } \\
\text { 11: Sustainable cities and } \\
\text { communities }\end{array}$ \\
\hline 'Myportablediary' & $\begin{array}{l}\text { An app to support } \\
\text { pregnant women and } \\
\text { raise awareness } \\
\text { about infant } \\
\text { screening tests }\end{array}$ & $\begin{array}{l}\text { Center for Preventive } \\
\text { Paediatrics }\end{array}$ & $\begin{array}{l}\text { 3: Good health and } \\
\text { well-being }\end{array}$ \\
\hline 'Learn Greek' & $\begin{array}{c}\text { An app to support newly } \\
\text { arrived migrants with } \\
\text { learning basic Greek }\end{array}$ & $\begin{array}{l}\text { Migrant Information } \\
\text { Center (Mihub) }\end{array}$ & $\begin{array}{l}\text { 4: Quality education } \\
\text { 10: Reduced inequalities } \\
\text { 16: Peace, justice and strong } \\
\text { institutions }\end{array}$ \\
\hline 'Pet Finder' & $\begin{array}{l}\text { An app to prevent } \\
\text { animal abuse }\end{array}$ & Pets2Adopt & $\begin{array}{l}\text { 16: Life on land } \\
\text { (Animal rights) }\end{array}$ \\
\hline
\end{tabular}

\section{Results and discussion}

Before conducting the analysis, the internal consistent reliability of the latent variables included in the study was tested by means of Cronbach's alpha (Ferreras-Méndez, Fernández-Mesa \& Alegre, 2019; Nunnaly \& Bernstein, 1994). The value obtained for each of the variables studies was higher than 0.7. Therefore, reliability was ensured. Furthermore, to ensure content validity, items from the literature which have already been tested were used (Sevilla-Pavón, 2019).

The results from the pre- and post-intervention whole-group pairedsample $t$-test associated with the perceived contribution of artefact-based tasks to the development of twenty-first century competences in the YES project (RQ1) are reported on Table 3 below.

Table 3. Pre- and post-intervention questionnaires whole-group mean paired-sample $t$-test results.

\begin{tabular}{|c|c|c|c|c|c|c|c|}
\hline & Variables & Mean & $\begin{array}{l}\text { Standard } \\
\text { deviation }\end{array}$ & $\begin{array}{l}\text { Pair } \\
\text { mean }\end{array}$ & $\begin{array}{c}\text { Pair standard } \\
\text { deviation }\end{array}$ & $t$-Value & $p$ Value \\
\hline \multirow[t]{2}{*}{ Pair 1} & MOT & 4.69 & 0.89 & -0.24 & 1.01 & -1.54 & 0.13 \\
\hline & MOTP & 4.93 & 1.10 & & & & \\
\hline \multirow[t]{2}{*}{ Pair 2} & AWA & 4.75 & 0.86 & -0.04 & 0.45 & -0.59 & 0.56 \\
\hline & AWAP & 4.79 & 0.83 & & & & \\
\hline \multirow[t]{2}{*}{ Pair 3} & LING & 5.04 & 1.17 & 0.61 & 1.51 & 2.62 & 0.01 \\
\hline & LINGP & 4.43 & 1.27 & & & & \\
\hline \multirow[t]{2}{*}{ Pair 4} & TEA & 5.21 & 0.89 & 0.13 & 0.91 & 0.90 & 0.37 \\
\hline & TEAP & 5.08 & 1.07 & & & & \\
\hline \multirow[t]{2}{*}{ Pair 5} & DIG & 5.35 & 1.25 & 0.06 & 1.43 & 0.29 & 0.77 \\
\hline & DIGP & 5.29 & 1.21 & & & & \\
\hline \multirow[t]{2}{*}{ Pair 6} & ANX & 4.29 & 1.03 & -1.11 & 1.24 & -5.78 & 0.00 \\
\hline & ANXP & 5.39 & 1.05 & & & & \\
\hline
\end{tabular}


As can be observed, the whole-group $(N=42) t$-test analysis results revealed significant differences in two of the six variables under investigation. The variable in which a statistically significant mean increase was observed was linguistic competence (scoring 5.03 in the post-questionnaire). Meanwhile, the theme in which a statistically significant mean decrease was observed was anxiety (4.28). As for the rest of variables, an increase was observed in motivation (scoring 4.93), intercultural competence (scoring 4.78), while a slight mean decrease was observed in teamwork (scoring 5.07 in the post-questionnaire) and digital competence (5.28). The relevant differences found in linguistic competence and anxiety can be interpreted as evidence that the YES project was perceived as useful in terms of the participants' linguistic development and the reduction of their initial anxiety. The positive scores awarded to motivation and intercultural awareness indicate, first of all, that participants found the YES initiative motivating and engaging, since the students' level of motivation remained high from the beginning to the end of the project and even increased slightly towards the end. Seemingly, participants awarded a high score to the variable concerning the development of their intercultural communication and awareness, and the initially high scores granted to this variable not only remained stable but also increased towards the end of the project. As for the rest of the variables, although there were minor variations between the pre- and post-questionnaire results, the fact that the scores remained around 4.5 (in a 7-point Likert scale) and above indicates that overall students were satisfied and found that the project had helped them develop the different competences under investigation. Seemingly, participants reported having felt comfortable in the new role as social entrepreneurs, and their co-constructed artefacts were aligned with several SDGs each. This was also corroborated by the analysis of the students' open-ended responses which will be discussed subsequently.

The students' qualitative responses further illustrate their perceptions with regard to their development of the twenty-first century skills under investigation, while shedding light on the ways in which the implementation of artefact-based telecollaborative tasks could foster social entrepreneurship in ESP contexts (RQ2). As far as the participants' levels of motivation and overall fulfilment of expectations regarding the project are concerned, the feedback received was highly positive, as shown in the statements from students below. These statements, which often overlapped, were organised around different main themes.

\subsection{Theme 1: usefulness and relevance to their contexts}

The first theme was 'Usefulness and relevance to the participants' contexts'. In this theme, students highlighted the relevance of the project to 
their social and academic contexts, current studies and future career around international business management, stressing, on the one hand, the project's usefulness as preparation to work in an international context or to become entrepreneurs; and on the other hand, the project's potential to address pressing social issues from the participants' respective local contexts:

The theme of 'Usefulness and relevance' connects to previous findings from the literature, such as Cunningham's (2019) study, which features a similar kind of mentorship which was perceived as having a high degree of usefulness and relevance to students' contexts and (future) careers. The author found that students who had been asked to conduct synchronous audiovisual interviews with entrepreneurs in Berlin so as to acquire more knowledge about German business culture were capable of linking existing knowledge to new knowledge while creating meaningful connections between different topical areas. Similarly, a Spanish YES participant pointed out the high number of benefits derived from the project, highlighting the great importance of English as a language of international communication, as illustrated by the following comment:

The benefits [of this project] are countless. Thanks to the project, we are able to realise how extremely useful the English language is in an international context. This is an activity that should be experienced at least once in our life, Spanish UV female student

As in Cunningham's (2019) study, one of the most highly valued elements of the project was the opportunity to learn about (social) entrepreneurship first-hand and in a more experimental, creative way, as pointed out by a Cypriot YES participant:

Social entrepreneurship was the most creative part (...) Also getting to think and develop out a new innovative idea got us into the game of business for real showing us the path for actually being an entrepreneur, Cypriot CUT male student

This theme can also be connected to Porto and Byram's (2015) findings. They underlined participants' high 'sense of commitment and responsibility towards others in their decision to undertake their specific civic action' and pointed out how they were willing to go well beyond what is usually required of students in a typical language class. The project was thus perceived as contributing to creating what Barnett (2011) considered 'the developmental university', that is, an institution which produces knowledge in and for the world and intends to improve it, as shown in the following statement:

We are both excited about the NGO's project because the members of the organization were very friendly with us and helpful. We helped them because they were trying to solve some of the existing problems and they were struggling for it, Cypriot CUT male student 


\subsection{Theme 2: intercultural learning}

A recurrent theme was 'intercultural learning'. In this theme, students' stressed the positive impact of their collaboration in terms of their learning about different countries, cultures, lifestyles, views and how this learning process had enabled them to increase their understanding of their virtual exchange partners' cultures.

'Intercultural learning' was also a recurrent theme in Porto and Yulita's $(2016$, p. 12, 13) study, who found 'evidence for the key components of intercultural citizenship in foreign language education' resulting from their project, namely: an international identification among participants regardless of their national or regional identifications; challenging stereotypes of each national group, 'through the skills involved in intercultural competence such as observing, discovering, describing, analysing, comparing and contrasting, relating, interpreting, perspective taking and de-centring'; and criticality involving new ideas gained and substantial changes reflected in concrete actions (Barnett, 1997). Similar to this, some of those key components were highlighted by YES project participants:

... what we enjoyed the most about this project is the chance to collaborate with people from other countries. This gave us the opportunity to learn about other countries, different cultures, lifestyles too. Also, we communicated about different projects and we exchanged our views about the app that we created, Cypriot CUT female student

The best things about the project are seeing the world with different eyes and increasing our level of understanding, communicating with people from another country, learning something new e.g. how to make a video, and trying to be more creative, Austrian UV female student

I enjoyed the project a lot and I am grateful to have collaborated with such nice Cypriot girls. I've never been to Cyprus before and don't have any friends from there, so it was really interesting to listen to first-hand information when they were talking about their culture and customs. Participating in the project was an amazing experience we will always remember, German UV female student

\subsection{Theme 3: linguistic and communicative competences}

Another theme that was frequently referred to in the students' interviews and written reflections was the project's contributions to the development of their linguistic and communicative competences. This theme frequently overlapped with the themes of intercultural learning and relevance to the participants' context.

The theme of 'linguistic and communicative competences', which has been present on the literature on virtual exchange for nearly two decades 
(Furstenberg, Levet, English, \& Maillet, 2001; O’Dowd, 2018), was sometimes connected to other project gains, such as intercultural communication, as shown below:

This project is a good and different way to learn English and improve some communication skills but it also requires a lot of time. [...] Despite the fact of the time required, I am very satisfied and happy to have had the opportunity to participate in this international project. What is more, I think that it benefits all the students from UV because we are studying International Business so probably, in the future, we will have to face similar situations, Spanish UV female student

We have had opportunities to speak in English and learn new words and enrich our knowledge, Cypriot CUT female student

... I feel really grateful and proud to have been close to people from other cultures.

I improved my English communication skills, mainly my pronunciation, Spanish UV female student

\subsection{Theme 4: digital competence}

The theme of 'Digital competence' was also stressed by YES participants, who considered that the project required being technologically-savvy and that thanks to this requirement they had developed their digital competence. This competence has been identified in the literature as one of the common educational goals that all virtual exchanges share (Guth \& Helm, 2010; O’Dowd, 2018):

[In this project] you need lot of technology skills, Cypriot CUT male student

The most beneficial aspects were talking with partners while practicing English and developing technological skills, Spanish UV male student

I have improved my skills developing a digital product, Cypriot CUT male student

\subsection{Theme 5: social entrepreneurship}

The theme of 'Social Entrepreneurship' was also mentioned by students in their interviews and written reflections who appear to have been inspired by the project to pursue a career as entrepreneurs or social entrepreneurs.

The theme of 'Social Entrepreneurship' is of special relevance, given the scarcity of previous studies reporting on projects around social entrepreneurship. Only recently, authors such as Cunningham (2019) have included the mentorship of entrepreneurs in virtual exchanges, and in line with her findings, this inclusion allowed YES participants to move from 'realistic' to 'real' situations and operations connected to entrepreneurship in general and, in the case of this project, with social 
entrepreneurship. In fact, some participants explicitly mentioned 'entrepreneurship' as a possible career path they would consider following, as shown in the following quotations by Cypriot participants:

I would consider becoming an entrepreneur in the future because I like to deal with the financial transactions and management of a company and I found it very interesting dealing with the various problems a business has, Cypriot CUT male student

If I find a good innovative idea maybe I will start my own business, Cypriot CUT male student

Being an entrepreneur is a good way to pursue your dreams, Cypriot CUT male student

Meanwhile, a Spanish student also referred to social entrepreneurship with an emphasis on its social dimension, understanding this concept as a synonym of a person who can change society for the better, as illustrated by the following quotation:

It is one of my dreams to become a social entrepreneur, a person who can make a difference, Spanish UV male student

\subsection{Theme 6: motivation and overall perceptions}

Finally, the students' comments in their interviews and written reflections point to their increased motivation levels to learn English at university. Previous studies have also reported an increase in participants' motivation because of participation in synchronous computer-mediated communication (Donaldson \& Kötter, 1999; Schenker, 2013; SevillaPavón, 2019; Sun, 2009). In line with these, YES participants considered the project a unique and enjoyable experience which helped them acquire various skills, as shown below:

You are able to learn with happiness and [that] gives you more motivation!, Cypriot CUT male student

I have had only one opportunity to study English in a multicultural and diverse setting and it was thanks to this project. It has been an amazing experience in which I have learned a lot from Cyprus and its culture. In addition, I have improved my English skills, Spanish UV female student

I hadn't had the opportunity to study English in a multicultural setting before. This was the first time I had the chance to practice my skills talking with other students [from abroad], Cypriot CUT female student

This was a great opportunity to get to know people from so many different countries and cultures, Austrian female UV student

Overall, as discussed above, the quantitative and qualitative results obtained indicate that the project was perceived by the whole group as 
having positively contributed to their motivation and the development of the different competences, especially linguistic, as well as intercultural skills, motivation and social entrepreneurial mindset. Participants' positive perceptions were expressed both numerically, with scores around or above 4.45 in a 7-point Likert scale and qualitatively, with the positive feedback provided by participants in their written reflections and focusgroup interviews.

Upon completion of the project, the students' co-created artefacts were analysed and categorised according to their alignment with the UNESCO's SDGs, which was related to RQ2 (the contribution of the implementation of artefact-based telecollaborative tasks to fostering social entrepreneurship in ESP contexts). Tables 1 and 2 above display some examples of the topics dealt with by each of the Cypriot and Spanish organisations which guided students in the process, as well as how those align with UNESCO's SDGs. Students came up with the different ideas after they had conducted a preliminary interview with one organisation, and the subsequent discussion and analysis, as well as brainstorming sessions. The analysis and brainstorming sessions were carried out in the Google + Communities by means of a discussion among the students and their foreign partners in their respective virtual exchange groups. Following that, the different team's proposed solutions were then presented in the form of digital stories (Sevilla-Pavón \& Nicolaou, 2020). Digital storytelling can be defined as the blend of the longstanding art of telling stories and the twenty-first century practice of putting together a variety of available multimedia tools, including graphics, audio, video, animation and web publishing (Lambert, 2002; Robin, 2008; Robin \& McNeil, 2012). This practice has been used in telecollaborative environments by authors such as Priego and Liaw (2017), who focused on how an intercultural, telecollaborative digital storytelling project could reveal the degrees of group functionality and the underlying reasons for tensions or contradictions emerging among groups as a result of their co-construction of multilingual digital stories. In the case of the digital artefacts produced in this project, the focus was the co-construction and sharing of authentic and meaningful artefacts for the promotion of social inclusion. Therefore, each of the digital stories students produced addressed the different SDGs tackled by their mentors from the organisations (Nicolaou, 2020; SevillaPavón, 2019).

The YES project's tasks allowed for the adoption of a Critical CALL perspective grounded in constructionism. Thus, the YES tasks promoted equality, social justice and awareness about the different issues dealt with while supporting the construction of artefacts that were meaningful to 
their constructors. Furthermore, those issues and their corresponding artefacts were connected with at least one of UNESCO's SDGs.

\section{Concluding remarks}

The YES virtual exchange was a technology-mediated project designed with a constructionist Critical CALL perspective which encouraged the co-creation and sharing of meaningful artefacts. Students were significantly engaged in the learning process using social technologies that supported the creation of an artefact (Parmaxi, Zaphiris \& Ioannou, 2016). With regard to RQ1, about how the implementation of artefact-based tasks in ESP contexts contributed to students' perceived development of twenty-first century competences, the results from the study conducted with 42 Cypriot and Spanish YES project participants indicate that it was perceived by the whole group as having positively contributed to their motivation and the development of different twenty-first century competences, especially linguistic as well intercultural competences and social entrepreneurial mindset, while reducing their anxiety.

The students' positive perceptions were expressed both numerically, with all the variables scoring above 4.5 in a 7 -point Likert scale; and qualitatively, in the form of satisfactory open-ended feedback from questionnaire responses, interviews and written reflections. Overall, the project was considered successful in achieving its main goals of connecting the classroom with the outside world through the involvement of local organisations, while fostering students' twenty-first century competences: intercultural, linguistic, digital, teamwork and social entrepreneurial mindset.

As for RQ2, regarding the ways in which the implementation of artefact-based telecollaborative tasks could foster social entrepreneurship in ESP contexts, the themes identified in participants' open-ended responses helped shed light on this aspect, especially themes 1 and 5, in which social entrepreneurship was especially prominent. The first theme, 'usefulness and relevance', in line with Cunningham's (2019) findings, showed that social entrepreneurship was perceived as the most relevant aspect of the project. Furthermore, mentorship was considered both useful and relevant to students' contexts and careers and helped them become more aware of the importance of English as an international language while providing them a first-hand, experimental and creative learning experience around social entrepreneurship. In addition, corroborating Porto and Byram's (2015) findings, participants displayed high levels of commitment and responsibility towards others when undertaking civic actions, going well beyond what is usually required of students in a typical language class and thus becoming social entrepreneurs within 'the 
developmental university' (Barnett, 2011), using their knowledge to improve society in their respective local contexts.

The constructionist, Critical CALL perspective adopted realised its full motivational and transformative potential by encouraging students to become social entrepreneurs whose work would involve making a positive change in their local communities. The analysis of the artefacts participants produced revealed the project's positive social impact: as a result of completing the different tasks with the guidance of representatives from different local NGOs and volunteer groups, the students became more aware of the various social issues faced in their respective contexts. These issues in turn were linked to both the organisations' missions and the SDGs, thus providing further information to answer RQ2. Because the SDGs and a Critical Pedagogy perspective were adopted and targeted in the project, participants took these goals into account when developing their ideas and when producing their artefacts. Thus, the following SDGs were tackled: no poverty, no hunger, good health and well-being, quality education, clean water and sanitation, affordable and clean energy, industry and innovation/infrastructure, reduced inequalities, sustainable cities and communities, life below water, life on land, peace and justice.

The involvement of local organisations from the civil society, despite being challenging initially, also helped give the project its social, critical focus which in turn rendered the artefacts constructed more meaningful to their constructors. Another positive aspect regarding the collaboration with different local organisations was that there was a knowledge gap which emerged from the fact that each participant only had access to the information pertaining to the kinds of challenges that the local organisations in their context were facing. This meant that students had to communicate with their foreign counterparts in order to find out about those same challenges in the foreign country and then come up with possible solutions by looking at the way the same issues were dealt with in other countries and contexts. Consequently, even students with a lower linguistic proficiency level were given the chance to become the more knowledgeable other (Vygotsky, 1978) in the exchange, as he/she had a valuable piece of information that their foreign partners did not have. By sharing this knowledge, they were becoming empowered when constructing their artefacts, as this process involved their cooperation and pursuit of common goals and shared learning (Sadler \& Dooly, 2016).

Regarding suggestions for pedagogical implementation, the implication for practice is that it is indeed possible and necessary to go beyond the syllabus and the classroom's physical four walls in order to foster solidarity, equality and respect in the broader social context. This in turn would empower students and practitioners while equipping them with the tools 
needed to tackle problems of discrimination, marginalisation and inequality (Andrejevic, 2002, 2007; Menezes de Souza, 2012), both in the classroom and in society. Furthermore, it is hoped that similar projects will be conducted so as to continue exploring ways to encourage participants to become active 'change champions' by raising their awareness of the significance of advocacy and social entrepreneurship in promoting social change.

As for the limitations of the study, they have to do with the small size of the sample (42 participants) and the lack of a comparison or control group. These limit the study's generalisability and therefore results should be interpreted with caution. Future studies might be conducted with a higher number of participants and the pre- and post-treatments results might be compared with the results obtained by a control group.

Future research could focus on the impact and relevance of connecting language students to their local contexts while learning about worldwide challenges through virtual exchange in current post-COVID19 pandemic environments, which has led many educational organisations to pivot to online teaching and has in many cases increased the divide between the 'privileged few' and those experiencing problems of discrimination, marginalisation and inequality.

\section{Notes}

1. Acknowledgements are due to the Spanish Ministry of Science, Innovation and Universities, research project VELCOME: Virtual exchange for learning and competence development in EMI classrooms (Ref: RTI2018-094601-B-100), for the period 2018-2021, for funding this research work.

2. Source: http://www.un.org/sustainabledevelopment/blog/2016/03/un-statistical-commissionendorses-global-indicator-framework/

\section{Acknowledgements}

This work was supported by the Spanish Ministry of Science, Innovation and Universities, under Grant VELCOME: Virtual exchange for learning and competence development in EMI classrooms (Ref: RTI2018-094601-B-100), for the period 2018-2021.

\section{Disclosure statement}

No potential conflict of interest was reported by the authors.

\section{Ethical statement}

I hereby declare that:

1. this material has not been published in whole or in part elsewhere;

2. the manuscript is not currently being considered for publication in another journal; 
3. the authors have been personally and actively involved in substantive work leading to the manuscript and will hold herself individually responsible for its content.

\section{Notes on contributors}

Ana Sevilla-Pavón is Associate Professor in the Department of English and German Philology at Universitat de València, Spain and holds a $\mathrm{PhD}$ in Applied Linguistics from Universitat Politècnica de València, Spain. Her current research interests include CALL, twenty-first Century Learning, English for Specific Purposes, Intercultural Communication and Virtual Exchange.

Anna Nicolaou is an English Language Instructor at the Language Centre of the Cyprus University of Technology. She holds a Ph.D. from Trinity College Dublin focusing on Intercultural Education and Global Competence learning through Virtual Exchange. Her research interests include Intercultural Education, Virtual Exchange, Global Competence and Computer-Assisted Language Learning.

\section{ORCID}

Ana Sevilla-Pavón (D http://orcid.org/0000-0001-5253-0423

Anna Nicolaou (D) http://orcid.org/0000-0001-8052-2201

\section{References}

Ackermann, E. (2001). Piaget's constructivism, Papert's constructionism: What's the difference. Future of Learning Group Publication, 5(3), 438.

Alessandrini, K., \& Larson, L. (2002). Teachers bridge to constructivism. The Clearing House: A Journal of Educational Strategies, Issues and Ideas, 75(3), 118-121. doi:10. $1080 / 00098650209599249$

Andrejevic, M. (2002). The work of being watched: Interactive media and the exploitation of self-disclosure. Critical Studies in Media Communication, 19(2), 230-248. doi: $10.1080 / 07393180216561$

Andrejevic, M. (2007). Surveillance in the digital enclosure. The Communication Review, 10(4), 295-317. doi:10.1080/10714420701715365

Barnett, R. (1997). Higher education: A critical business. Buckingham: Open University Press.

Barnett, R. (2011). Being a university. London: Routledge.

Bornstein, D. (2007). How to change the world. New York: Oxford University Press.

Burbules, N., \& Berk, R. (1999). Critical thinking and critical pedagogy: Relations, differences, and limits. In T. Popkewitz \& L. Fendler (Eds.), Critical theories in education: Changing terrains of knowledge and politics (pp. 45-65). New York: Routledge.

Cakir, M. (2008). Constructivist approaches to learning in science and their implications for science pedagogy: A literature review. International Journal of Environmental \& Science Education, 3(4), 193-206.

Council of Europe. (2001). Common European framework of reference for languages: Learning, teaching, assessment. Cambridge: Cambridge University Press.

Crookes, G. (2013). Critical ELT in action: Foundations, promises, praxis. New York: Routledge. 
Cunningham, D. J. (2019). Telecollaboration for content and language learning: A Genre-based approach. Language Learning \& Technology, 23(3), 161-177.

Donaldson, R. P., \& Kötter, M. (1999). Language learning in cyberspace: Teleporting the classroom into the target culture. Calico Journal, 16(4), 531-558. Retrieved from https://journals.equinoxpub.com/index.php/CALICO/article/view/23350/19355. doi:10. 1558/cj.v16i4.531-557

Erkmann, M., Petersen, A. K., \& Christensen, P. L. (2019). The three spaces model for online CPD. Designs for Learning, 11(1), 118-126. doi:10.16993/dfl.107

Ferreras-Méndez, J. L., Fernández-Mesa, A., \& Alegre, J. (2019). Export performance in SMEs: The importance of external knowledge search strategies and absorptive capacity. Management International Review, 59(3), 413-437. doi:10.1007/s11575-01900379-6

Freire, P. (1973). Education for critical consciousness. New York: Seabury.

Freire, P. (1981). Ação cultural para a liberdade (5th ed.). Rio de Janeiro: Paz e Terra.

Freire, P. (1987). Pedagogia do oprimido (17th ed.). Rio de Janeiro: Paz e Terra.

Freire, P. (2003). Política e Educação (7th ed.). São Paulo: Cortez.

Furstenberg, G., Levet, S., English, K., \& Maillet, K. (2001). Giving a virtual voice to the silent language of culture: The culture project. Language Learning \& Technology, 5(1), 55-102. http://www.lltjournal.org/item/2342.

Genet, R. (2010). The Soliya Connect Program at ENSIMAG, France. In: S. Guth \& F. Helm (Eds.), Telecollaboration 2.0: Language, literacies and intercultural learning in the 21st century (pp. 399-412). Bern: Peter Lang.

Giroux, H. A. (2006). Henry Giroux on critical pedagogy and the responsibilities of the public intellectual. In H. A. Giroux (Ed.), America on the edge (pp. 3-20). New York: Palgrave Macmillan. doi:10.1057/9781403984364_1

Guth, S., \& Helm, F. (Eds). (2010). Telecollaboration 2.0: Language, literacies and intercultural learning in the 21st Century. Bern: Peter Lang. doi:https://doi.org/10.3726/ 978-3-0351-0013-6

Helm, F. (2013). A dialogic model for telecollaboration. Bellaterra Journal of Teaching \& Learning Language \& Literature, 6(2), 28-48.

Helm, F. (2015). The practices and challenges of telecollaboration in higher education in Europe. Language Learning \& Technology, 19(2), 197-217. http://lt.msu.edu/issues/ june2015/helm.pdf.

Kohn, K., \& Hoffstaedter, P. (2017). Learner agency and non-native speaker identity in pedagogical lingua franca conversations: Insights from intercultural telecollaboration in foreign language education. Computer Assisted Language Learning, 30(5), 351-367. doi:10.1080/09588221.2017.1304966

Kynigos, C., \& Futschek, G. (2015). Re-situating constructionism. Constructivist Foundations, 10(3), 281-284.

Lambert, J. (2002). Digital storytelling: Capturing lives, creating community. Berkeley: Digital Diner.

Lindner, R. (2016). Developing communicative competence in global virtual teams: A multiliteracies approach to telecollaboration for students of business and economics. CASALC Review, 1, 144-156.

Menezes de Souza, L. M. (2012). Engaging the global by resituating the local. In: V. O. Andreotti \& L. M. Menezes de Souza (Eds.), Postcolonial perspectives on global citizenship education. New York \& London: Routledge.

Muirhead, B. (2002). Book review of E-tivities: The key to active online learning. Educational Technology \& Society, 5(4), 1-3. 
Nicolaou, A. (2020). The affordances of virtual exchange for developing global competence and active citizenship in content-based language learning (Unpublished $\mathrm{PhD}$ thesis, School of Linguistics, Speech and Communication Studies, Centre for Language and Communication Sciences). Trinity College, Dublin.

Nunnaly, J. C., \& Bernstein, I. H. (1994). Psychometric theory. Sydney: McGraw-Hill.

O'Dowd, R. (2011). Online foreign language interaction: Moving from the periphery to the core of foreign language education? Language Teaching, 44 (3), 368-380. doi:10. $1017 / \mathrm{S} 0261444810000194$

O'Dowd, R. (2016). Learning from the past and looking to the future of online intercultural exchange. In: R. O'Dowd \& T. Lewis (Eds.), Online intercultural exchange: Policy, pedagogy, practice (Vol. 17, p. 273). London: Routledge.

O’Dowd, R. (2018). From telecollaboration to virtual exchange: State-of-the-art and the role of UNICollaboration in moving forward. Journal of Virtual Exchange, 1, 1-23. doi:10.14705/rpnet.2018.jve.1

O’Dowd, R., \& Waire, P. (2009). Critical issues in telecollaborative task design. Computer Assisted Language Learning, 22(2), 173-188. doi:10.1080/09588220902778369

Papert, S. (1980). Mindstorms: Children, computers, and powerful ideas. New York: Basic Books.

Papert, S. (1986). Constructionism: A new opportunity for elementary science education. Proposal to the National Science Foundation. Cambridge: MIT Media Laboratory.

Papert, S. (1993). The children's machine: Rethinking school in the age of the computer. New York: Basic Books.

Parmaxi, A., Zaphiris, P., \& Ioannou, A. (2016). Enacting artifact-based activities for social technologies in language learning using a design-based research approach. Computers in Human Behavior, 63, 556-567. doi:10.1016/j.chb.2016.05.072

Partnership for 21st Century Skills. (2009). P21's framework for 21st century learning. Retrieved from http://www.p21.org/about-us/p21-framework

Pennycook, A. (2001). Critical applied linguistics: A critical introduction. Mahwah, NJ: Lawrence Erlbaum.

Pennycook, A. (2016). Politics, power relationships and ELT. In: G. Hall (Ed.), The Routledge handbook of English language teaching. Routledge Handbooks Online. Abingdon: Routledge.

Piaget, J. (1936). Origins of intelligence in the child. London: Routledge \& Kegan Paul.

Piaget, J. (1945). Play, dreams and imitation in childhood. London: Heinemann.

Piaget, J. (1957). Construction of reality in the child. London: Routledge \& Kegan Paul.

Porto, M., \& Byram, M. (2015). A curriculum for action in the community and intercultural citizenship in higher education. Language, Culture and Curriculum, 28(3), 226-242. doi:10.1080/07908318.2015.1087555

Porto, M., \& Yulita, L. (2016). Language and intercultural citizenship education for a culture of peace: The Malvinas/Falklands Project. In: M. Byram, I. Golubeva, H. Hui, \& M. Wagner (Eds.), From principles to practice in education for intercultural citizenship. languages for intercultural communication and education (pp. 199-224). Bristol: Multilingual Matters.

Priego, S., \& Liaw, M. L. (2017). Understanding different levels of group functionality: Activity systems analysis of an intercultural telecollaborative multilingual digital storytelling project. Computer Assisted Language Learning, 30(5), 368-389. doi:10.1080/ 09588221.2017.1306567

Robin, B. (2008). Digital storytelling: A powerful technology tool for the 21 st century classroom. Theory into Practice, 47 (3), 220-228. doi:10.1080/00405840802153916 
Robin, B., \& McNeil, S. (2012). What educators should know about teaching digital storytelling. Digital Education Review, 22, 37-51. http://revistes.ub.edu/index.php/der/ article/view/11294.

Sadler, R., \& Dooly, M. (2016). Twelve years of telecollaboration: What we have learnt. ELT Journal, 70(4), 401-413. doi:10.1093/elt/ccw041

Salmon, G. (2013). E-tivities: The key to active online learning. London: Routledge.

Schenker, T. (2013). The effects of a virtual exchange on students' interest in learning about culture. Foreign Language Annals, 46 (3), 491-507. doi:10.1111/flan.12041

Sevilla-Pavón, A. (2019). L1 versus L2 online intercultural exchanges for the development of 21st century competences: The students' perspective. British Journal of Educational Technology, 50(2), 779-805. doi:10.1111/bjet.12602

Sevilla-Pavón, A., \& Nicolaou, A. (2017). Online intercultural exchanges through digital storytelling. International Journal of Computer-Assisted Language Learning and Teaching (IJCALLT), 7(4), 44-58. doi:10.4018/IJCALLT.2017100104

Sevilla-Pavón, A., \& Nicolaou, A. (2019). Business English 3.0: Hands-on online and virtual collaboration tasks. Granada: Comares.

Sevilla-Pavón, A., \& Nicolaou, A. (2020). Online intercultural exchanges through digital storytelling revisited. In: I. Management Association (Ed.), Language learning and literacy: Breakthroughs in research and practice (2 Volumes, pp. 757-773). Hershey, PA: IGI Global. doi:10.4018/978-1-5225-9618-9.ch039

Sun, Y.-C. (2009). Voice blog: An exploratory study of language learning. Language Learning \& Technology, 13(2), 88-103.

Taras, V., Bryla, P., Gupta, S.F., Jiménez, A., Minor, M.S., Muth, T., ... Zdravkovic, S. (2012). Changing the face of international business education: The X-Culture project. AIB Insights, 12(4), 11-17.

UNESCO. (2005). UN decade of education for sustainable development 2005 - 2014: The DESD at a glance. Paris: UNESCO. Retrieved from http://unesdoc.unesco.org/images/ 0014/001416/141629e.pdf

UNESCO. (2015). Transforming our world: The 2030 agenda for sustainable development. United Nations Sustainable Development knowledge platform. General Assembly Distr.: General 21 October 2015, Seventieth session, Agenda items 15 and 116 Resolution adopted by the General Assembly on 25 September 2015. Retrieved from https://sustainabledevelopment.un.org/post2015/transformingourworld/publication

UNESCO. (2017). Education for sustainable development goals: Learning objectives. Paris: UNESCO. Retrieved from http://unesdoc.unesco.org/images/0024/002474/247444e.pdf UNICEF. (1993). UNICEF annual report 1993. New York: UNICEF.

Vygotsky, L. S. (1978). Mind in society: The development of higher psychological processes. Cambridge, MA: Harvard University Press.

Warschauer, M. (2003). Technology and social inclusion: Rethinking the digital divide. Cambridge, MA: MIT Press. 